\title{
METÁFORAS DA VIDA CO(T)VIDIANA
}

\section{METAPHORS WE LIVE (FIGHTING) BY}

\author{
José Teixeira ${ }^{1}$ \\ CEH da Universidade do Minho-Portugal
}

Resumo: A separação tradicional entre denotação-conotação, sentido literal e sentido figurado, sentido não metafórico e sentido metafórico baseia-se numa longa tradição em que estas dicotomias são vistas como constituindo dois planos separados. A perceção dos falantes que, mesmo não sendo linguistas, percebem as diferenças entre os dois planos, reforça esta visão dicotómica dos dois níveis como instâncias paralelas de significação. Neste texto, através da explanação e análise à forma como a metáfora PROTEÇÃO (CONTRA O VÍRUS) É GUERRA está a ser usada pela comunicação social portuguesa, procuraremos demonstrar que esses dois planos tradicionais não devem ser vistos como planos paralelos, mas antes como níveis com possibilidade de convergência, em virtude de poder variar o grau de distância semântica (e figuratividade) entre sentido não metafórico e sentido metafórico.

Palavras chave: Metáfora Concetual; Conotação; Sintonímia; Distância Semântica.

${ }^{1}$ Endereço eletrônico: jsteixeira@ilch.uminho.pt 
Abstract: The traditional gap between denotation and connotation, literal sense and figurative sense, nonmetaphorical sense and metaphorical sense is based upon a long tradition in which these dichotomies are seen as constituting two separate standpoints.

Even though they are not linguists, the perception of speakers reinforces this dichotomous view of the two levels as parallel instances of meaning.

In this text, through the analysis of how the PROTECTION (AGAINST THE VIRUS) IS WAR metaphor is being used by the Portuguese media, we will attempt to convey that these two traditional plans should not be seen as parallel plans, but rather as levels with the possibility of convergence. Furthermore, we argue that this possibility of convergence is justified because the degree of semantic distance (and figurativeness) between non-metaphorical and metaphorical meanings may vary.

Keywords: Conceptual Metaphor; Connotation; Syntonymy; Semantic Distance.

\section{AS METÁFORAS E A VIDA}

Falar, no início de um texto académico, da relação entre a vida e as metáforas pode parecer uma forma de vencer a síndroma do escritor perante a angústia do papel em branco.

Mas talvez não seja só isso. A visão tradicional da metáfora reservava-lhe um papel "especial" dentro da linguagem: era uma "figura de estilo", um "desvio", como genericamente as visões estruturalistas a viam, dotada, também, da "ininterpretabilidade" que o generativismo lhe atribuiu. Portanto, a metáfora era tudo menos o funcionamento normal, habitual, da língua da vida cotidiana.

E então aparece a reviravolta lakoff-johnsoniana ${ }^{2}$.

E até Steven Pinker, não tendo a mesma visão cognitiva de Lakoff e Johnson, concorda que Metaphors We Live By (LAKOFF; JOHNSON, 1980) é uma obra "extraordinária":

A lingüística já exportou várias grandes idéias para o mundo intelectual.

[...] Até por esses padrões, a teoria da metáfora conceitual de Lakoff é extraordinária. Se ele estiver certo, a metáfora conceitual pode fazer qualquer coisa, desde virar de cabeça para baixo 2500 anos de equivocada confiança na verdade e na objetividade no pensamento ocidental. (PINKER, 2008, p. 284)

\footnotetext{
${ }^{2}$ Não fica muito elegante o termo e é pouco habitual esta referência àquilo que, normalmente, se designa por visão ou teoria "lakoffiana" da metáfora. Mas fica mais justa. Convenhamos que a obra seminal que lhe deu origem é dos dois, embora muitas vezes o segundo autor, Mark Johnson, fique por referir.
} 
Lakoff-Johnson vêm trazer a metáfora para a vida do dia a dia porque conseguem mostrar-nos a metáfora na vida do dia a dia. O maior mérito da obra de Lakoff e Johnson talvez tenha sido o de provar e focar mais insistentemente que quaisquer outros anteriores a eles que a metáfora não é algo anormal, mas um fenómeno do viver/falar da vida cotidiana, não é apenas uma técnica linguística, mas também um processo percetivo que se espelha em variadas formas e expressões. E é por isso que se pode aceitar que o título Metaphors We Live By possa ter sido traduzido, em outras línguas, como Les Métaphores dans la Vie Quotidienne (Minuit, Paris); Metáforas de la vida cotidiana (Catedra, Madrid) e Metáforas da Vida Cotidiana, (Mercado de Letras, no Brasil).

Desde o início da obra, Metaphors We Live By sublinha que a metáfora é um fenómeno da linguagem do cotidiano:

[...] a metáfora interpenetra a linguagem e o pensamento cotidianos evidência que não se encaixava em nenhuma teoria contemporânea angloamericana sobre o significado, quer dentro da linguística ou da filosofia. A metáfora tem sido tradicionalmente vista, em ambos os campos, como uma questão de interesse periférico. Compartilhamos a intuição de que é, em vez disso, uma questão central, talvez a chave para a explicação mais adequada da compreensão. (LAKOFF; JOHNSON, 1980, p.7, tradução nossa) ${ }^{3}$.

Temos, assim, que se a metáfora é um fenómeno do cotidiano irá refletir as formas mais marcantes dessas vivências. E se o nosso cotidiano (nos tempos em que este texto está a ser escrito) $)^{4}$ é absolutamente dominado por uma temática tão global e omnipresente como nenhuma outra o foi na história da humanidade, então, numa grande parte, as metáforas cotidianas serão metáforas covidianas.

3 "metaphor is pervasive in everyday language and thought-evidence that did not fit any contemporary Anglo-American theory of meaning within either linguistics or philosophy. Metaphor has traditionally been viewed in both fields as a matter of peripheral interest. We shared the intuition that it is, instead, a matter of central concern, perhaps the key to giving an adequate account of understanding" (LAKOFF; JOHNSON, 1980, p.7)

${ }^{4}$ Setembro de 2020. 


\section{USOS NÃO METAFÓRICOS E USOS METAFÓRICOS}

\subsection{Dois planos ou níveis de significado?}

Como atrás se referiu, a perspetiva tradicional vê os usos metafóricos como essencialmente diversos e separados dos usos não metafóricos. Essa perspetiva permitiu (e permite, para a generalidade) também a separação entre sentidos denotativos e sentidos conotativos. As palavras (metaforizáveis e não só), nesta ótica, possuem dois níveis de significado: um assentando essencialmente na objetividade e referencialidade diretas (sentido denotativo) e outro apontando para valores diferentes deste sentido, dito denotativo.

É esta a perspetiva dominante e por isso genericamente adotada, inclusivamente pelo Ministério da Educação e Ciência de Portugal que a explica, assim, no Dicionário Terminológico que serve de referência para o ensino secundário:

Denotação: Significado literal e estável de uma palavra ou expressão.

[Não tem exemplos]

Notas: Denotação define-se por oposição a conotação.

Conotação: Significado(s) secundário(s) associado(s) a uma palavra ou expressão que não corresponde(m) ao seu sentido literal.

Exemplos: Na frase "A minha camisa é vermelha", a palavra "vermelha" tem valor denotativo; na frase, "Ele é um sindicalista vermelho", a palavra "vermelho" tem valor conotativo evocando uma filiação partidária ou desportiva.

Notas: Conotação define-se por oposição a denotação ${ }^{5}$.

Conotação e denotação, entendidas deste modo, implicam que se veja o significado de uma palavra como estratificado em dois níveis, separados e perfeitamente distinguíveis. É interessante consultar as páginas de divulgação e explicação sobre conteúdos linguísticos e ver como é uma visão de dualidade inquestionável que opõe os dois níveis de valor que, nesta perspetiva, uma palavra pode ter:

5 Dicionário Terminológico, Ministério da Educação e Ciência, disponível em: http://dt.dge.mec.pt/. Acesso em: 11 set. 2020. 
O sentido conotativo é a linguagem em que a palavra é utilizada em sentido figurado, subjetivo ou expressivo.

Ele depende do contexto em que é empregado, sendo muito utilizado na literatura. Isso porque, no meio literário, muitas palavras têm forte carga de sensações e sentimentos.

Por sua vez, o sentido denotativo é a linguagem em que a palavra é utilizada em seu sentido próprio, literal, original, real, objetivo. Ele é, muitas vezes, caracterizado como o sentido do dicionário, ou seja, que contém a primeira acepção da palavra.

Nos dicionários, depois da acepção denotativa há uma abreviação, normalmente entre parênteses (fig), a qual indica o sentido figurado da palavra, ou seja, o sentido conotativo.

Exemplos:

Ele comeu bola na prova de matemática. (sentido conotativo)

Depois de jogar bola, nós comemos um churrasco. (sentido denotativo)

Com os exemplos acima, podemos ver que o sentido figurado, ou conotativo, foi utilizado na primeira oração, uma vez que "comer bola" significa" cometer um erro. Não poderíamos, no entanto, utilizar essa expressão no sentido real, uma vez que "comer bola" é algo impensável. (TodaMatéria) ${ }^{6}$

A partir das definições e exemplos apresentados, pode-se, em esquema, visualizar os dois níveis separados em que esta perspetiva organiza o significado linguístico das palavras ou expressões. O elemento DS, no esquema (Figura 1), procura representar a Distância Semântica que marca a separação entre denotação e conotação.

Figura 1 - Visão dicotómica tradicional entre denotação e conotação

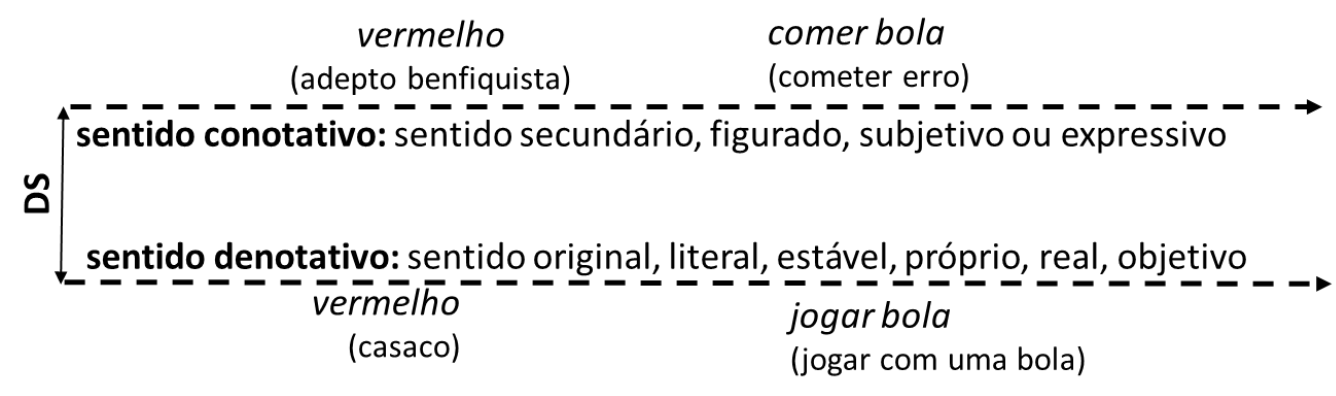

Fonte: Próprio autor

Obviamente que ninguém quer negar que há uma (grande) distância semântica entre os usos da mesma palavra/expressão nos exemplos apresentados e outros que se poderiam apresentar: toda a conhecida metaforização de guerra

${ }^{6}$ Disponível em: https://www.todamateria.com.br/conotacao-e-denotacao/ Acesso em: 11 set. 2020. 
na linguagem do futebol, por exemplo, demonstra que o falante sabe muito bem que quando se diz "aquele golo matou o jogo", "O campeonato é uma guerra que temos de vencer", "o tiro de Ronaldo fuzilou o guarda-redes", "foi um resultado esmagador" não se está a usar o sentido físico que as palavras matar, guerra, tiro, fuzilar, esmagar podem ter, como se se tratasse de uma guerra no sentido original7.

Mas será que a organização mental do léxico tem, para cada palavra, duas "prateleiras", uma com o significado denotativo e outra com o conotativo, ou que as palavras têm duas faces, uma denotativa não figurada e outra conotativa, figurada? Na verdade, na visão tradicional, há sempre uma separação, uma barreira entre o sentido denotativo (dito "real") e o conotativo (dito "figurado"). Embora explicitamente não se afirme isto, a linguística estruturalista e generativista da análise sémica componencial das Condições Necessárias e Suficientes (CNS) nunca conseguiu explicar a forma como a mesma palavra (ou expressão) organiza denotação/conotação, sentido real/figurado, organização sem nenhuma dificuldade para os utilizadores da língua. Estes problemas da linguística nunca o foram para os falantes.

\subsection{A perspetiva cognitiva integradora dos dois planos}

O enfoque cognitivo da análise linguística prefere visões menos dicotómicas e mais gradualizantes, visões que concebem o fenómeno linguístico e os seus usos como assentando em modelos mais complexos do que o mecanicismo do $[+X]$ por oposição a $[-X]$. Portanto, também aqui, não será de admirar que se entenda que a metáfora-não metáfora, denotação-conotação possa ser uma questão de grau ou que a figuratividade da linguagem pode variar em função de múltiplos fatores presentes na comunicação verbal.

$7 \mathrm{O}$ uso da linguagem da guerra no vocabulário do desporto e do futebol é temática abundantemente estudada. Ver, por exemplo, Teixeira (2010). 
Para a aceitação da não dicotomia radical entre os dois planos de que temos vindo a falar, contribuem os conceitos de metaforicidade e de figuratividade.

O conceito de metaforicidade ("metaphoricity"), ou seja, o de que há graus de metaforização numa expressão metafórica, embora possa parecer muito recente e apenas ligado ao âmbito da metáfora concetual é, na verdade, tão antigo como a própria visão retórica da metáfora. Na realidade, a distinção tradicional entre metáforas vivas e metáforas mortas (a figura retórica da catacrese) não é mais do que o reconhecimento de que as expressões metafóricas vão "morrendo", vão deixando de ter o funcionamento (cognitivo e linguístico) que "à nascença" teriam tido. O conceito de metaforicidade pode ir desde o papel que os gestos têm no uso e processamento metafórico (MÜLLER, 2008), da maior ou menor intensidade volitiva (MÜLLER, 2011) ou do cerne da questão, de como umas metáforas são mais metáforas que outras (DUNN, 2011).

A questão da metaforicidade prende-se, inexoravelmente, com a da literalidade-figuratividade e por isso a noção de figuratividade ("figurativity", em COULSON; OAKLEY 2005) abarca os dois âmbitos, sendo, na realidade, um conceito muito semelhante ao de metaforicidade. Cognitivamente, seria interessante tentar perceber as variadas inter-relações entre o processamento do sentido literal e do sentido figurado, se tal processamento envolve ou não estratégias cognitivas diferenciadas. Os dados disponíveis parecem não permitir conclusões muito definitivas (GIORA, 2002) e talvez no atual estado de conhecimentos que podemos obter sobre o funcionamento neuro-cognitivo não seja o aspeto neuronal o mais urgente a querer certificar.

A visão cognitiva resolve a questão dos dois planos do significado sem grandes problemas, sobretudo pela proposta de substituir a ideia de que a organização semântica da palavra se faz por traços semânticos necessários e suficientes (CNS) e oposições duais de presença/não presença, pela ideia das relações de centralidade prototípica. 
Esta mudança de paradigma que a chamada teoria do protótipo provocou como teoria para explicar as representações concetuais começa até fora do âmbito linguístico propriamente dito, mas ligada aos estudos de psicologia de Eleanor Rosch (ROSCH, 1973; ROSCH, 1975). No entanto, desde cedo a proposta da prototipicidade é integrada por Lakoff na relação entre a organização categorial e o funcionamento linguístico (LAKOFF, 1987). Posteriormente, o conceito de "embodied meaning" ou significado corporizado nas abordagens cognitivas (LAKOFF, 1995) combina-se com a noção de protótipo para apresentar os fenómenos ligados ao significado como envolvendo toda a atividade cognitiva corporal e socialmente integrada.

Nesta visão cognitiva que parte da base concetual dos fenómenos cognitivos, a organização concetual do significado de uma qualquer palavra não possui usos dotados sempre do mesmo estatuto concetual, mas usos mais prototípicos e usos mais periféricos relativamente ao centro prototípico. Enquanto para a análise componencial todas as ocorrências de cadeira ou pássaro possuem o mesmo estatuto semântico e o mesmo valor dentro do conceito (porque partilhariam semas/traços supostamente comuns), para a visão cognitiva da organização prototípica há umas cadeiras que concetualmente são mais cadeiras do que outras (e para os pássaros, ou para outro conceito qualquer, a mesma coisa.... $)^{8}$. Assim, desde os usos prototípicos até aos usos periféricos, há (podemos chamar-lhe) uma distância semântica que o falante domina e que lhe permite, sem qualquer dificuldade, verificar se essa mesma distância é maior ou menor, ou seja, se a palavra está a ser usada no sentido mais ou menos figurado? ${ }^{9}$ Imaginemos o esquema da Figura 2 para representar a organização concetual

\footnotetext{
${ }^{8}$ Para ver este aspeto sobre a organização prototípica da concetualização, ver Teixeira (2005).

${ }_{9}^{9}$ Pode falar-se também em grau de figuratividade. Não é muito rigoroso, no entanto, associar denotação/conotação, sentido próprio/sentido figurado a membros ou usos prototípicos/ membros ou usos não prototípicos porque estão implicadas duas visões diferentes do funcionamento das línguas naturais e da organização lexical. No entanto, globalmente, a organização prototípica dos usos lexicais abarca, na totalidade, o que tradicionalmente se dividia entre denotação/conotação, sentido/próprio/sentido figurado.
} 
prototípica da palavra vermelho. O uso da palavra em casaco vermelho seria um uso prototípico ( $\mathrm{V}^{1}$ ou próximo) ao passo que o uso de vermelho=adepto benfiquista estaria mais próximo dos valores assinalados como periféricos ( $\mathrm{V}^{4}$, por exemplo).

Figura 2 - Esquema representativo da estrutura prototípica

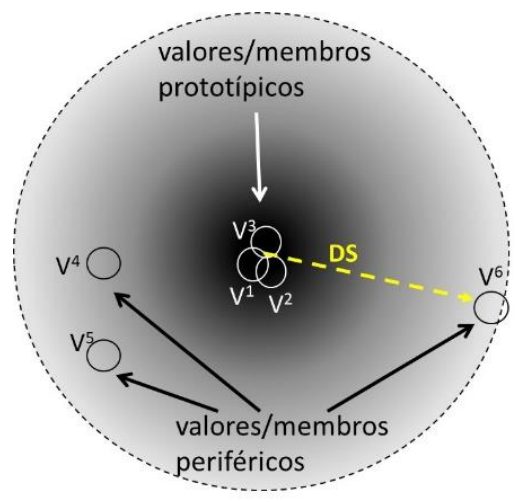

Fonte: próprio autor

Repare-se, no entanto, que esta perspetiva introduz uma visão muito diferente da visão da denotação/conotação. Agora não há separação de planos, não há graus ou níveis de significado, mas uma gradação entre os vários valores ou usos. Não é preciso decidir se o uso é não metafórico ou metafórico, não figurado ou figurado, denotativo ou conotativo ${ }^{10}$. É todo um contínuo gradativo de valores a que se recorre e não a dois planos independentes.

Para mostrar que não há dois planos completamente distintos, mas apenas um continuum organizado em protótipo, aproveitámos o exemplo da palavra vermelho dado pela Terminologia Linguística do nosso Ministério da Educação e Ciência. E é interessante reparar que não é um exemplo do que se considera metáfora, mas de metonímia (CLUBE POR COR DO CLUBE). Isto acontece porque o chamado "sentido figurado" engloba um conjunto bastante vasto de relações semântico-cognitivas. Que metáfora e metonímia não são realidades separadas, mas fenómenos que se interpenetram, já é pacificamente aceite nos estudos cognitivos mais recentes. $\mathrm{O}$ conceito de metaftonímia baseia-se

${ }^{10} \mathrm{E}$, na realidade, os falantes (e muitos linguistas...) têm muita dificuldade em fazer as distinções sobre se o valor é denotativo ou conotativo quando os usos não são muito diferenciados. 
precisamente na ideia da gradatividade e implicação entre os fenómenos metafóricos e metonímicos (GOOSSENS, 1990; BARCELONA, 2000). E, em nossa opinião, pode ir-se mais longe. A partir de algumas centenas de inquéritos, onde se analisaram associações que os falantes fazem entre cores e significado (em 9 provérbios portugueses) pode inferir-se que, de forma sistemática, as cores são associadas pelos falantes inquiridos a expressões e palavras/conceitos, mesmo quando estes não estão diretamente relacionados com cores. Designámos estas inter-relações metáfora-metonímia-sinestesia por sintonímia ${ }^{11}$. Na realidade, constata-se, sem grande dificuldade, que os valores das cores evocados pelos provérbios só se explicam pelo funcionamento conjunto daqueles três processos cognitivos como gradativos, contínuos e não discretos (metonímia, metáfora, sinestesia). Não é difícil de crer que as associações cognitivas são multifacetadas e não se dividem rigidamente em, ou apenas metonímia, ou apenas metáfora, ou apenas sinestesia. A Figura 3 procura representar (1) a visão tradicional da separação metáfora-metonímia, (2) a integração da metaftonímia e (3) a proposta da integração sintonímica.

Figura 3 - Esquema da proposta do conceito de sintonímia

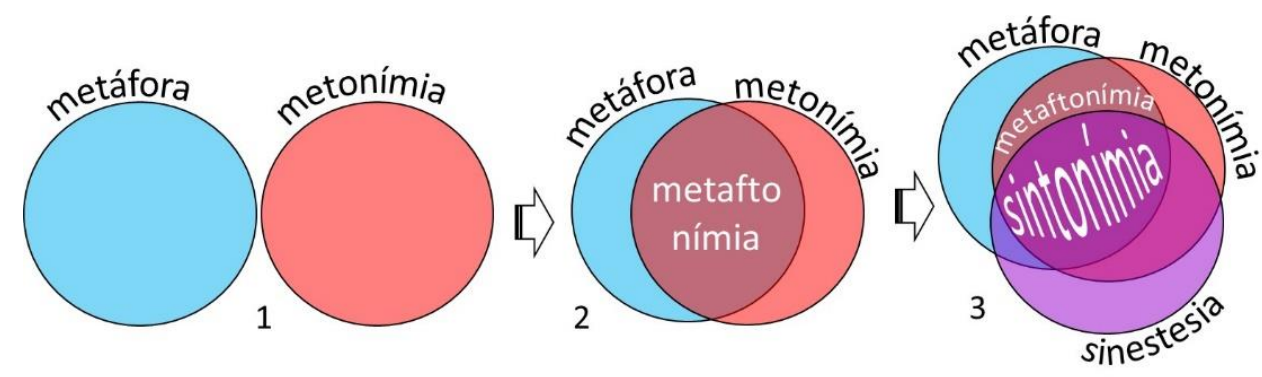

Fonte: próprio autor

A nível neurológico, parece também que será mais acertado admitir que as associações que os neurónios fazem são de múltiplas vertentes, são todas as possíveis que podem fazer. Pelos dados fornecidos pela neurocognição, parece

\footnotetext{
${ }^{11}$ Este aspeto da relação metonímia-metáfora-sinestesia e o conceito de sintoníma, aqui apenas aflorado, pode ser visto com maior desenvolvimento em Teixeira (2018), Teixeira (2019a), Teixeira (2019b) e Teixeira (no prelo).
} 
que os neurónios são viciados em procurarem associações. Sapolsky ${ }^{12}$ apresenta um esquema do funcionamento entrecruzado dos neurónios, em camadas:

O Neurónio A dispara em direção aos Neurónios 1, 2 e 3; o Neurónio B dispara para o 2, 3 e 4, e assim por diante. [...]

O conhecimento do Neurónio 3 é geral e vem da sobreposição das projeções das primeiras camadas. Os Neurónios 2 e 4 são também generalistas, mas menos precisos porque só possuem dois exemplares cada.

Então o Neurónio 3 encontra-se no centro convergente dessa rede. E as partes mais sofisticadas do cérebro estão ligadas, em grande parte, de forma similar a este circuito de mentira: a um só tempo, o Neurónio 3 é um elemento periférico nalgum outro circuito e envia projeções para ele - digamos, um circuito que poderia ser desenhado de forma perpendicular a esta página ao passo que o Neurónio 1 está no centro de alguma outra rede na quarta dimensão, e assim por diante. Todos esses neurónios estão inseridos em múltiplas redes.

E o que produz isso? A capacidade de fazer associações, metáforas, analogias, parábolas, símbolos. De relacionar duas coisas díspares, inclusive de diferentes modalidades sensoriais. De associar homericamente a cor do vinho com a cor do mar, de entender que tanto «tomate» quanto «batata» podem ser pronunciados de forma distinta numa música, de notar que uma língua vermelha de fora nos faz lembrar as músicas dos Stones. E por isso que associamos Stravinsky a Picasso, dado que os discos (lembra-se disso?) de Stravinsky pareciam ter sempre uma pintura de Picasso na capa. E é por isso que um pedaço retangular de tecido com um padrão distintivo de cores pode representar um país inteiro, um povo ou uma ideologia. (SAPOLSKY, 2018, p. 829-831)

Parece, pois, não ser difícil de admitir que os nossos neurónios procuram constantemente associações e são essas associações que permitem os fenómenos que tradicionalmente designamos por metonímias, metáforas, sinestesias como se fossem fenómenos de âmbito muito diferente, quando não serão mais do que nomes diferentes que damos aos resultados de variadas associações cognitivas que a mente processa.

\subsection{Há umas metáforas mais metáforas do que outras}

A descrição de Sapolsky (2018) reforça a necessidade de não esquecer a tendência para o correlacionamento que parece ser a caraterística mais

${ }_{12}$ Professor de ciências biológicas e neurológicas na Universidade Stanford. 
fundacional dos neurónios. Ou seja, o nosso sistema cognitivo está constantemente a procurar correlações e a organização concetual e as palavras que a retratam incorporam essas correlações que, a nível lexical, não são mais do que as tradicionais conotações. O erro está em concebê-las num plano separado ao plano "normal" do significado da palavra. Essas "conotações" fazem parte do significado normal, sem aspas. "Vermelho", em português (especialmente na variante do Português Europeu), não significa apenas uma cor ou uma tonalidade dessa cor, mas significa também "adepto do Benfica", "simpatizante de ideologias de esquerda", "cartão de expulsão de jogadores no futebol", "pessoa ruborizada, com as faces avermelhadas" e tantas outras vertentes que compõe o conceito organizado prototipicamente.

Só que, como atrás vimos (Figura 2), não é necessário supor dois planos de significado, mas apenas um, em que pode haver maior ou menor distância semântica entre o centro prototípico e o uso/valor menos central. Isto implica (como defende a teoria cognitiva do protótipo) que cognitivamente correlacionamos os sentidos, sabemos automaticamente se eles são muito ou pouco afastados do núcleo prototípico. Por conseguinte, a distância semântica entre o sentido prototípico (classicamente, "denotativo") e os sentidos correlacionados (classicamente "conotativos/figurados/metafóricos") pode ser maior ou menor. $\mathrm{O}$ falante pode estruturar um sentido metafórico como estando perto do sentido prototípico/central, ou vê-lo como bastante afastado dele. "Lutar pela bola": para uns, lutar terá um sentido muito metafórico, mas para outros pode ser pouco metafórico e tendem a interpretá-lo nesta vertente. O jogo de futebol como luta/guerra pode não ser metafórico no mesmo grau para todos. ${ }^{13}$

Isto implica que a continuarmos a querer falar de dois níveis de significado, o do significado prototípico e o dos significados correlacionados

\footnotetext{
${ }^{13}$ Basta assistir ao vivo a um jogo de futebol (de preferência nas bancadas dos adeptos comuns, não nas dos VIPs) para se ver como é pequeno o grau de metaforização ou figuratividade da metáfora da luta e da guerra no futebol. O comportamento belicoso de muitos adeptos antes e no fim do jogo acentua esta dimensão do jogo como luta.
} 
("conotativos/ figurados/ metafóricos, ...") temos de aceitar que não se estruturam em dois planos paralelos, mas em planos com distâncias semânticas variáveis. Alguns exemplos mostram que esta visão é mais adequada. Na palavra linha, o valor/uso "linha=linha de coser" tem uma grande distância semântica do valor/uso "linha em geometria euclidiana", já que este conceito de linha é antiintuitivo porque viola os mecanismos da nossa perceção cognitiva habitual: este conceito de linha implica aceitar que tem comprimento mas não tem espessura nem largura, o que é impossível construir pela perceção habitual. Já em “o rei era a cabeça da nação", o desvio semântico de cabeça, relativamente ao protótipo cabeça do corpo humano, é menor: é a habitual atribuição pelos processos que são sentidos como nítidos processos de metaforização. Mas nestes processos, a dimensão de metáfora pode variar (e varia), como já atrás assinalámos, entre os falantes. E assim, a distância semântica será maior entre cabeça do corpo humano e cabeça da nação do que entre lutar na segunda guerra mundial e lutar pela bola em cada jogada. Aqui, lutar é "menos metáfora" do que cabeça nos exemplos dados, ou seja, as duas metáforas possuem diferentes distâncias semânticas entre os respetivos sentidos prototípicos e os sentidos metafóricos, como na Figura 4 podemos visualizar.

Figura 4 - Esquema da variação da distância semântica na metaforização

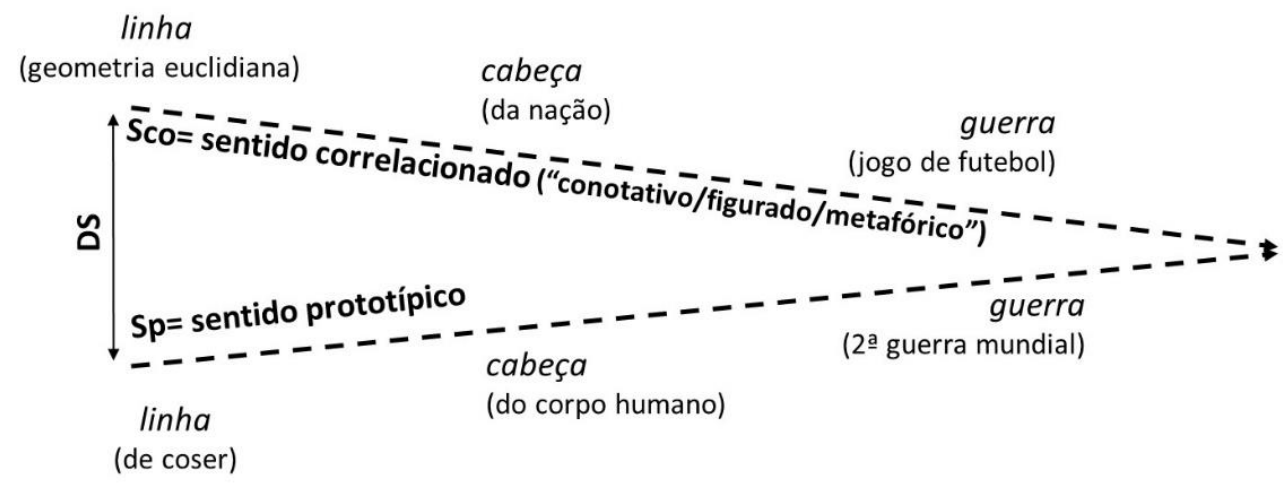

Fonte: próprio autor

Isto equivale a dizer que também o conceito de metáfora é prototípico, ou seja, que, tal como acontece com os conceitos para as cadeiras, os pássaros ou o vermelho, há algumas metáforas que são mais metáforas do que outras. 


\section{AS METÁFORAS DA VIDA COVIDIANA}

Procurámos, até aqui, fazer ressaltar que a distância entre expressão metafórica e não metafórica não tem sempre a mesma saliência, mas configura um contínuo que vai da separação nítida até à quase identificação. E, a nosso ver, os usos metafóricos usados nos média relativos à temática da designada COVID19 fornecem indícios suficientemente sólidos de que, na metáfora concetual dominante, a metáfora da guerra, podemos verificar como ela foi frequentemente utilizada nesta dimensão: tentar reduzir ao mínimo a distância semântica entre sentido prototípico, não metafórico, e sentido metafórico.

\section{1 "...De uma verdadeira guerra se trata"}

As metáforas de guerra podem aparecer aplicadas em vários domínios, desde o do jogo, como já atrás referimos, até ao da discussão (ARGUMENT IS WAR, em LAKOFF; JOHNSON, 1980). Não será, portanto, de estranhar que no domínio da prevenção contra um vírus, ou qualquer doença mais disseminada, surjam metáforas de luta ("lutar contra a doença"). A especificidade das surgidas no contexto COVID-19 está em que, mais do que de luta, são metáforas de guerra. Mais: para determinados atores políticos, convém até que nem sejam vistas como metáforas, ou seja, que o recetor tenda a interpretar a metáfora como se valesse pelo seu sentido prototípico, como se o referente não fosse uma situação de não guerra metaforizada em guerra, mas uma verdadeira guerra o referente real. Ou seja, estes atores políticos (ainda que talvez não conscientemente) intuíram que a distância semântica nas metaforizações não é sempre a mesma e que pode ser encurtada, caso se consiga fazer da expressão metafórica uma expressão referencial.

É sintomático que o discurso da declaração do Estado de Emergência pelo Presidente da República portuguesa revele, logo nos primeiros parágrafos, esta situação. Num contexto de declaração solene ao país, usando precisamente a figura constitucional do Estado de Emergência (que costuma ser reservado para 
situações de guerra), logo nos primeiros parágrafos, aplica à situação da proteção contra o contágio a metáfora da guerra, mas reforçando imediatamente que não é uma guerra metafórica (não usa esta formulação) mas uma guerra real, uma "verdadeira guerra" ("Esta guerra, porque de uma verdadeira guerra se trata..."). Quase todo o discurso está imbuído de expressões referentes a guerra, procurando que os portugueses interiorizem que "de uma verdadeira guerra se trata" como explicitamente afirma. Perdoe-se o tamanho da exemplificação, mas ela torna-se necessária para se perceber como as metáforas de guerra usadas o foram numa contextualização muito convincente sobre as guerras que os portugueses travaram no passado e que lhes permitiram o milagre da existência como povo (o destaque é nosso):

[...] Esta guerra, porque de uma verdadeira guerra se trata, dura há um mês, começou depois (da) dos vizinhos europeus; também por isso pode demorar mais tempo a atingir os picos da sua expressão. [...]

E os portugueses, com a experiência de quem já viveu tudo, numa história de quase 9 séculos, disciplinaram-se, entenderam que o combate era muito duro, $e$ muito longo e foram e têm sido exemplares. [...]

O Governo, que tem entre mãos uma tarefa hercúlea, adotou medidas tentando equilibrar contenção no espaço público e nas fronteiras e não paragem da vida económica e social, medidas que todos, presidente, parlamento, partidos, parceiros sociais, apoiamos, conscientes de que só a unidade permite travar e depois vencer guerras. [...] [A declaração do estado de emergência] Não é, porém, uma vacina, nem uma solução milagrosa que dispense o nosso combate diário [...]

[...] num ponto, os especialistas são claros: depende da contenção nas próximas semanas o conseguirmos encurtar prazos, poupar pacientes e sobretudo salvar vidas. Temos, pois, todos de fazer por contribuir para ir o mais longe e o mais depressa possível nesta luta desigual e quanto mais depressa formos, mais depressa poderemos salvar vidas [...]

[...] temos de fazer a nossa parte, manter viva a nossa economia: assim é em tempo de guerra. As economias não podem morrer.

Termino com um pedido

Nesta guerra, como em todas as guerras, só há um efetivo inimigo. Invisível, insidioso e por isso perigoso, que tem vários nomes: desânimo, cansaço, fadiga do tempo que nunca mais chega ao fim. Temos que lutar todos os dias contra ele. Contra o desânimo pelo que corre mal ou menos bem. Contra o cansaço de as batalhas serem ainda muitas e parecerem difíceis de ganhar. Contra a fadiga, que tolhe a vontade, aumenta as dúvidas, alimenta indignações e revoltas. Tudo o que nos enfraquecer e dividir nesta guerra alongará a luta e torná-la-á mais custosa e dolorosa. Resistência, solidariedade e coragem são as palavras de 
ordem. E verdade, porque nesta guerra ninguém mente nem vai mentir a ninguém. Isto vos diz e vos garante o Presidente da República [...]

O caminho ainda é longo, é difícil e é ingrato. Mas não duvido um segundo sequer que vamos vencê-lo o melhor que pudermos e soubermos. Na nossa história vencemos sempre os desafios cruciais. Por isso temos quase 900 anos de vida. Nascemos antes de muitos outros e existiremos ainda quando eles já tiverem deixado de ser o que eram e como eram.

Deixem-me terminar com um exemplo de como somos: o exemplo da neta enfermeira que no dia em que perdeu o seu avô, a primeira vítima mortal, me dizia: "presidente, já só faltam 9 dias para eu regressar à luta. Somos assim porque somos Portugal. (fim do discurso) ${ }^{14}$.

E a mensagem foi muito eficaz, porque a imprensa, globalmente, aceitou falar da situação efetivamente como se de uma verdadeira guerra se tratasse, fazendo títulos de capa (e o estar nas capas é indicador da importância) com a mensagem de guerra, desde revistas de referência (Figura 5), o mais vendido jornal diário (Figura 6) e até jornais desportivos (Figura 7).

Figuras 5,6 e 7 - Capas impressas da revista Sábado e dos jornais Jornal de Notícias e O Jogo
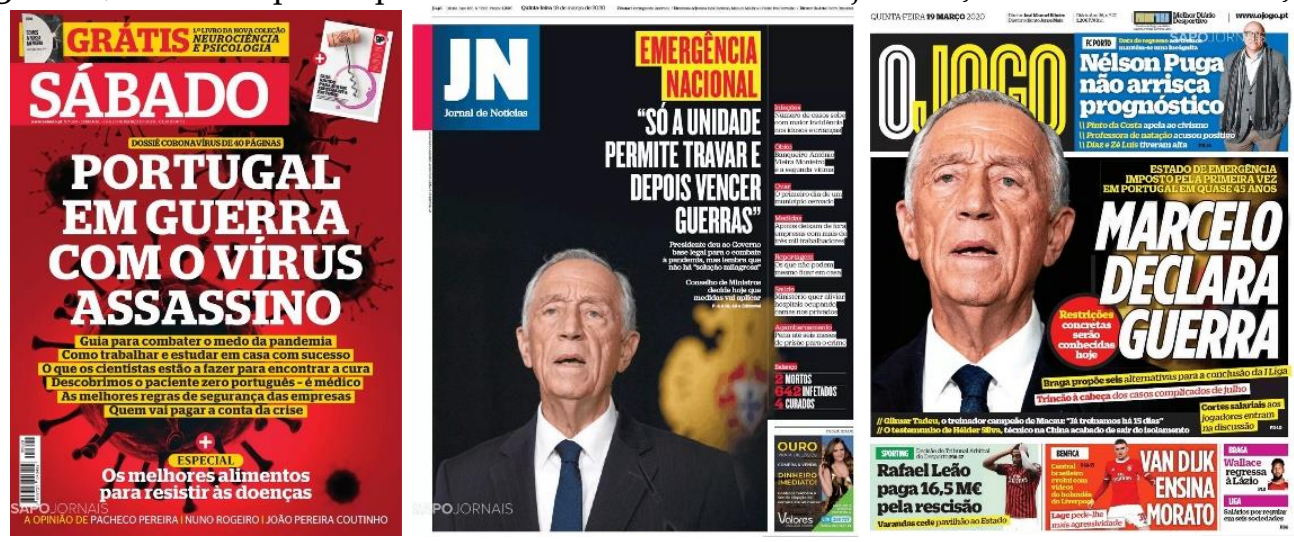

É sintomático o Editorial do jornal diário mais vendido (Jornal de Notícias), intitulado "Juntos nesta trincheira" (19/3/2020), que corrobora as expressões de guerra (formalmente metafóricas, mas entendidas como mais próximas da realidade do que da metáfora): “Como tão apropriadamente o caracterizou o presidente da República, Marcelo Rebelo de Sousa, na comunicação solene que fez ao país para explicar os contornos da declaração do estado de emergência,

${ }^{14}$ Declaração do Estado de Emergência de 18 de março de 2020. Disponível na Página Oficial da Presidência da República, http://www.presidencia.pt/?idc=21\&idi=176060. Acesso em: 10 fev. 2021. 
estamos no meio de uma guerra." ${ }^{15}$ Ou seja: a expressão que o Presidente utilizou, "estamos no meio de uma guerra", segundo o jornal, é a expressão que melhor carateriza a situação ("Como tão apropriadamente o caracterizou”). E o Editorial termina assim: "Porque não há outra forma de vencer esta guerra que não seja deste modo: juntos, numa trincheira invisível a disparar coragem sobre um inimigo que não tem rosto." 16

\subsection{Porque é que uma metáfora pode ser vista como "um exagero e um excesso de linguagem"?}

O uso de metáforas e expressões metafóricas de guerra para a situação da COVID-19, se já o era até aí, tornou-se quase asfixiante na imprensa, dando, por vezes, a ideia de que parecia estar a falar-se mesmo de uma guerra. Isso levou a que, na própria imprensa, surgisse o debate sobre até que ponto a guerra verbalmente expressa poderia ser interpretada como uma guerra real.

No semanário mais conceituado do país (Expresso), o Editorial desse fim de semana ${ }^{17}$ abordava a temática:

A declaração do estado de emergência, uma prerrogativa acionada na quinta-feira e desenhada para o caso de uma guerra civil, serviu que nem uma luva à narrativa que nos últimos dias usou abundantemente a metáfora da guerra para o "combate" ao novo coronavírus. Tomar esta pandemia como uma batalha pode, no entanto, ser um erro, até porque é cada vez mais provável não ser possível ganhá-la. Pelo menos enquanto não existirem vacinas. $\mathrm{O}$ vírus continuará a viver entre nós e é bem possível que a única vitória sobre ele seja a sua integração. (Editorial, Expresso 21/3/2020). ${ }^{18}$

É interessante verificar que, se por um lado o jornal sente que a metáfora da guerra pode ser nociva porque pode ser tomada como "pouco metafórica" e

15 Editorial na edição impressa e online, disponível em: https://www.jn.pt/opiniao/editorialjuntos-nesta-trincheira-11951908.html: Acesso em: 10 fev. 2021.

16 Editorial na edição impressa e online, disponível em: https://www.jn.pt/opiniao/editorialjuntos-nesta-trincheira-11951908.html: Acesso em: 10 fev. 2021.

17 Este jornal/semanário sai apenas ao sábado.

18 Edição impressa e online para assinantes, disponível em: https://leitor.expresso.pt/semanario. Acesso em: 21 mar. de 2020. 
interpretada como descrevendo uma verdadeira guerra, por outro lado termina com expressões metafóricas da mesma metáfora concetual, assumindo, mesmo, que a situação é de guerra. As últimas linhas do mesmo editorial são:

Um dos últimos grandes líderes da história cresceu com o lema: “Na guerra, determinação; na derrota, resistência; na paz, boa vontade." Que tenhamos líderes à altura. Que todos estejamos à altura. (Editorial, Expresso $21 / 3 / 2020) \cdot{ }^{19}$

As expressões de guerra, quanto menos metafóricas e mais "reais" forem assumidas, mais favorecem as perspetivas da necessidade de comando: destacam o papel dos líderes a quem se deve dar todo o poder, fazem ver tudo como uma questão de quem ganha e quem perde, captam a nossa benevolência para confiar em quem comanda. São metáforas nitidamente de reforço de comando. Não foi por acaso que todos os chefes de governo subiram em intenções de voto e em popularidade nas sondagens. Por isso, não é de admirar que esta metáfora não seja aceite por quem, por questões de princípio ou ideologia, não quer conceder demasiado poder aos líderes e discordou da declaração oficial do Estado de Emergência:

Ao contrário do que se diz, isto não é uma guerra. Nas guerras perde-se ou ganha-se. Nisto, pondera-se o impacto da doença e da cura. E é por isso que os políticos não podem ser comandados pelo medo das pessoas, por mais insuportável que seja a pressão. (Daniel Oliveira, Não morrer da cura, Expresso 21/3/2020) $)^{20}$.

O debate foi bastante generalizado, como resumidamente o jornal Sol refere:

Marcelo Rebelo de Sousa utilizou oito vezes a palavra guerra, na comunicação que fez ao país, para definir a crise que estamos a atravessar devido ao coronavírus. O Presidente da República não tem dúvidas de que estamos a enfrentar «uma verdadeira guerra». Não foi o primeiro a associar a Pandemia da COVID-19 a uma guerra, mas há quem considere um exagero e um excesso de linguagem.

19 Edição impressa e online para assinantes, disponível em: https://leitor.expresso.pt/semanario. Acesso em: 21 mar. de 2020.

20 Edição impressa e online para assinantes, disponível em: https://leitor.expresso.pt/semanario. Acesso em: 21 mar. de 2020. 
«É preciso ter cuidado com os excessos», afirmou Pacheco Pereira, na TVI 24. O comentador e ex-deputado do PSD considera que «não vale a pena estar com esta linguagem», porque esta pandemia «não pode ser interpretada como um conflito».

O social-democrata Miguel Morgado também fez um apelo aos políticos para que «não abusem da analogia da 'guerra'», porque «nem todas as catástrofes» são guerras. «Não é só um defeito de imaginação política e moral. É que o efeito inicial de mobilização da população rapidamente se desfaz precisamente porque a presente calamidade não é uma guerra».

A ex-secretária de Estado da Educação Ana Benavente também escreveu um post no facebook a contestar o excesso de linguagem. «As palavras não são neutras. Guerras implicam armas que matam, militares e tropas, vencidos e vencedores, campos opostos, barbaridades várias». [...] (Luís Claro, Faz sentido falar em guerra?, Jornal Sol, 21/3/2020)21.

Esta necessidade sentida de combater a ideia de que não estamos numa verdadeira guerra denota a intuição do sentimento de que esta metaforização antivírus estava a ser interpretada quase literalmente, ou seja, não era atribuída grande distância semântica entre o plano metafórico e o plano referencial. Até porque os jornais noticiavam constantemente que, em alguns países, havia muitos mortos, doentes, hospitais onde não cabiam mais pessoas que eram deixadas sem assistência, a morrer e, mesmo as pessoas sem a doença, impedidas de sair de casa, tentando, os que podiam, fugir para zonas mais distantes, rurais e mais isolados dos grandes centros, como acontece numa verdadeira guerra. $\mathrm{O}$ Diário de Notícias resume a situação em Espanha usando um título em que guerra não está no domínio metafórico: “Em Espanha, o cenário é de guerra” quer dizer "é mesmo um cenário de guerra autêntica". E justifica: "Nas últimas 24 horas morreram quase 400 pessoas. O país vizinho soma neste momento 28573 infetados e 1725 mortos. O primeiro-ministro Pedro Sánchez anunciou o prolongamento do estado de emergência e os médicos dizem que estão a viver a

\footnotetext{
21 Jornal Sol de 21/3/2020 impresso; também disponível em: https://www.sol.sapo.pt/artigo/689908/faz-sentido-falar-em-guerra. Acesso em: 10 fev. 2021.
} 
'guerra da nossa geração'" (Catarina Pires, Em Espanha, o cenário é de guerra, Diário de Notícias, 22 março 2020) ${ }^{22}$.

Mas por que razão se contesta, então, o uso da metáfora da guerra no combate ao vírus? Não se discutiria do mesmo modo se é lícito usar a expressão “o Presidente é a cabeça da nação", "os teus olhos são estrelas" ou "o teu sorriso é o meu sol", embora aqui sim, em rigor haja "um exagero e um excesso de linguagem", razão apontada para não se dever referir a proteção contra o vírus como guerra. Toda a gente sabe que as nações não são uma pessoa, não têm cabeças, os olhos não são estrelas e o Sol é uma estrela e não um sorriso. Mas a metáfora é isso mesmo, normalmente "excede" a realidade, até de uma forma quase absurda ou mesmo absurda sem ninguém se admirar nem querer proibir. Então, por que razão esta metáfora concetual da guerra covidiana foi (é) polémica e classificada como "exagero e excesso de linguagem" e vista, por alguns, como devendo ser evitada? Precisamente porque ela é interpretada quase como não metáfora, há demasiada proximidade entre o seu valor metafórico e o seu valor referencial.

Um indício interessante sobre a perceção da situação como de verdadeira "guerra" foi dado por um comportamento aparentemente inexplicável: o enorme aumento da venda de armas para particulares nos Estados Unidos, que mesmo a

22 Disponível em: https://www.dn.pt/mundo/em-espanha-o-cenario-e-de-guerra11967552.html. Acesso em: 10 fev. 2021. O sentir que se trata "quase" numa verdadeira guerra não acontece $(\mathrm{u})$ apenas na Europa. Uma aluna chinesa a viver na China, quando lhe perguntei como era lá transmitida a perceção da situação escreveu o seguinte: "Em relação à metáfora de guerra, nos jornais chineses é mais ou menos a mesma coisa [que em Portugal]. Na verdade, nos últimos meses, os médicos e enfermeiros eram elogiados como heróis e foram recebidas com saudação militar quando entraram nas regiões mais afetadas para ajudarem a população local. Além disso, a sociedade chinesa tornou num modo de guerra no final de janeiro. O governo bloqueou os movimentos populacionais (incluindo o transporte público e carros privados) e cancelou todas as atividades públicas. Foram fechadas a maioria das lojas, exceto alguns supermercados. Até ao início de março, a cada família foi permitida a saída de apenas uma pessoa para comprar a comida necessária, no máximo, três vezes por semana. O resto da família deveria ficar em casa. (email de 23 março 2020). 
imprensa portuguesa referiu como uma curiosidade surpreendente ${ }^{23}$ ou ironizando com o aparente absurdo (Figura 8).

Figura 6 - Bartoon

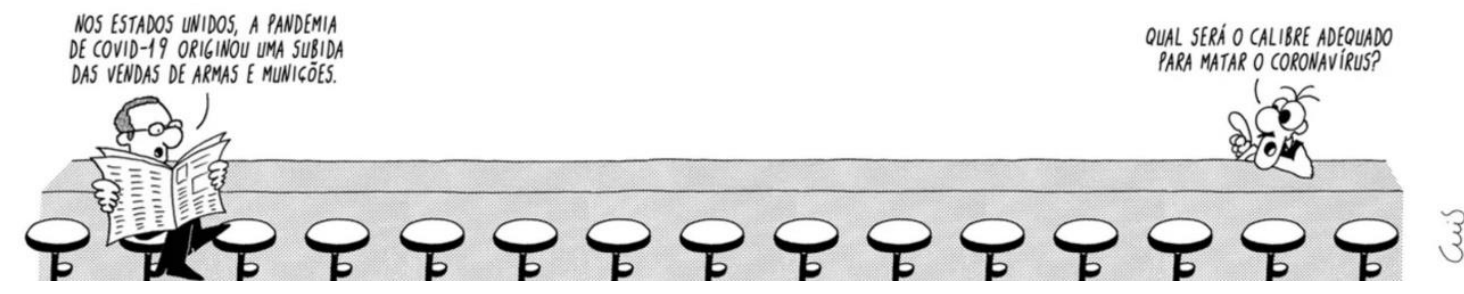

Fonte: Jornal Público, 20/3/202024

Mas talvez este facto não seja tão surpreendente se compreendermos a simbologia social e cognitiva que o uso de armas tem para muitos americanos. Em situações tidas como de perigo, o inconsciente de muita gente, na cultura americana, associa a necessidade de segurança, de defesa, ao uso de armas. A "guerra" ao vírus não se faz com as armas das guerras não metafóricas, mas como esta "guerra" foi sentida como quase real e pouco metafórica o inconsciente coletivo buscou na compra de armas a resposta à perceção sentida de uma guerra real.

A partir do que fomos realçando sobre a forma como na imprensa se retratam os usos metafóricos de guerra aplicados à situação da COVID-19, pode

\footnotetext{
${ }^{23}$ Site da Agência Efe (https://www.efe.com 9): “as compras impulsionadas pelo medo dos possíveis efeitos do novo coronavirus também levaram ao aumento nas vendas de armas nos Estados Unidos, com compradores a aglomerarem-se em estabelecimentos especializados em cidades como Los Angeles.

Longas filas de compradores foram vistas neste fim de semana em frente à loja de armas Martin B. Retting, em Culver City, no condado de Los Angeles, o que levou o local a publicar uma mensagem na sua conta do Facebook a pedir desculpas aos clientes por não permitir testes em algumas das armas e por não poder atender todos.

As vendas de armas também subiram online.

O site "Ammo.com", que vende munições online, também viu um aumento recente nas vendas.

Segundo a empresa, de 23 de fevereiro a 4 de março, as transações aumentaram $68 \%$ em comparação aos 11 dias anteriores, informou o jornal Los Angeles Times."

Disponível em: https://www.efe.com/efe/portugal/destacada/venda-de-armas-nos-euaaumenta-devido-ao-medo-dos-efeitos-do-coronavirus/50000440-4197630. Acesso em: 16 set. 2020.

24 Publicado na edição impressa e também disponível online em: https://www.publico.pt/bartoon. Acesso em: 10 fev. 2021.
} 
inferir-se como óbvia (parece-nos) a constatação de que as metáforas podem ser sentidas como "muito ou pouco metafóricas", ou seja, os falantes não atribuem a todas o mesmo desvio semântico, sendo as da guerra covidiana sentidas quase como expressões de referencialidade direta.

Poderemos, agora, completar o esquema da Figura 4, proposto atrás, com o esquema da Figura 9, procurando visualizar não apenas como é diferente a distância semântica entre metáforas com Fontes e Alvos diferentes (para linha, cabeça e guerra) como também pode variar a diferença semântica em metáforas com a mesma Fonte e Alvos diferentes (JOGO DE FUTEBOL É GUERRA, PROTEÇÃO DO CORONAVÍRUS É GUERRA).

Figura 7 - Relação de gradatividade entre os usos prototípicos e não prototípicos

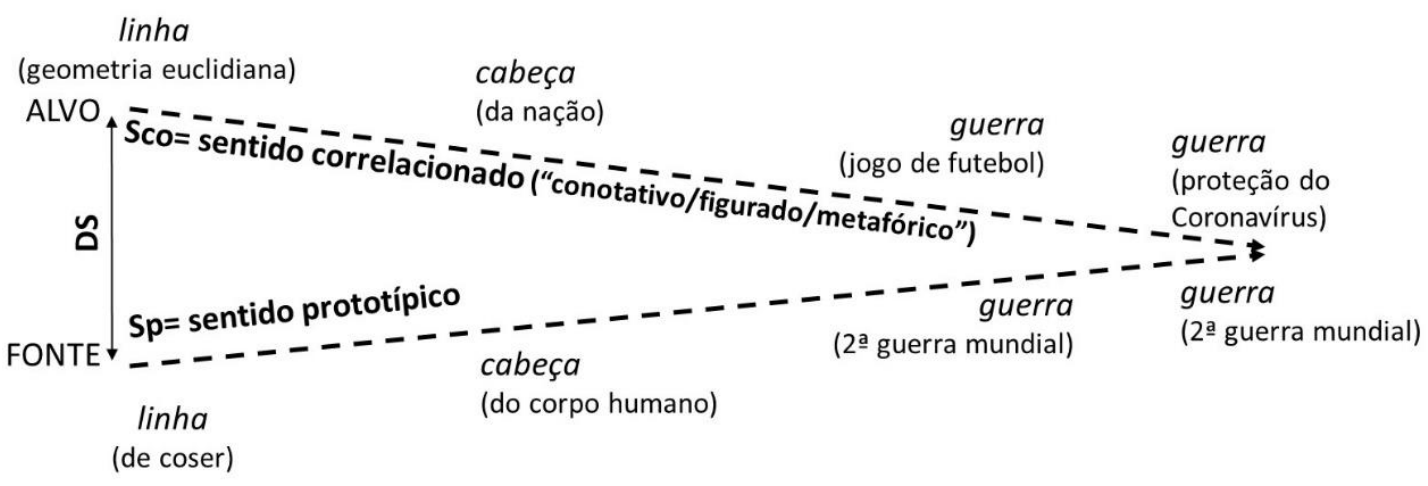

Fonte: próprio autor

Este esquema permite conciliar a perspetiva tradicional, estruturalista, com a perspetiva cognitiva. Na realidade, aceita os dois planos de significado, a oposição denotativo/conotativo, não figurado/figurado, conciliando isto com a teoria do protótipo, já que a noção de Distância Semântica permite compreender o porquê de haver maior ou menor desvio entre os dois planos.

\section{AS METÁFORAS DE GUERRA ENTRE AS METÁFORAS DA VIDA COVIDIANA}

As metáforas de guerra sobre a COVID-19 talvez sejam as que mais soundbites originam nos média. No entanto, elas nem são as metáforas nucleares 
da rede covidiana veiculada pela imprensa, já que as primárias serão, naturalmente, as que metaforizam o próprio vírus.

Esta rede metafórica será, como todas, uma estrutura aberta, e nenhum trabalho de recolha a pode representar completamente. Não será também essa a intenção deste texto, mas apenas a de, em esquema, situar a metáfora concetual aqui usada, PROTEÇÃO DO VÍRUS É GUERRA, relativamente à rede metafórica mais alargada da COVID-19.

Antes de mais, é fundamental reconhecer a utilidade do conceito de metaftonímia (por isso atrás abordado) para poder entrar na referida rede metafórica. O nome técnico do vírus é SARS-CoV-2, assim mesmo, com maiúsculas, uma minúscula e um número. Mas raramente ele é usado para referir o vírus, preferindo-se coronovírus ou COVID-19, embora, em rigor, não sejam referências equivalentes. Mas como a linguagem cotidiana não é rigorosa mas metaftonímica, qualquer destas referências é usada, muitas vezes, como se todos fossem termos sinónimos. E a prova disso é, por exemplo, aparecer escrito, como tantas vezes aparece na imprensa e no uso diário, "o COVID" em vez de "a COVID", já que COVID equivale a "doença do vírus corona" (COronaVIrusDesease). Usar o masculino indicia, naturalmente, referência (metonímica) ao vírus.

Idêntica equivalência metonímica acontece ao dizer-se "infetado por COVID" (e os exemplos em jornais, sites oficiais -até de centros hospitalares- e relatos orais são inúmeros ${ }^{25}$ ). Não é a doença que infeta, é o vírus. A doença é o

${ }^{25}$ Apenas a título de exemplo: "Acha que esteve infetado com COVID-19?" (Jornal Correio da Manhã, disponível em: https://www.cmjornal.pt/mundo/detalhe/acha-que-esteve-infetadocom-covid-19-conheca-os-sintomas-que-nao-deve-ignorar-e-podem-persistir-apos-recuperar. Acesso em: 10 fev. 2021; "Sabe o que fazer se alguém em sua casa ficar infetado pelo \#COVID19?", site do Hospital Privado de Chaves, disponível em: https://hpchaves.pt/sabe-o-quefazer-se-alguem-em-sua-casa-ficar-infetado-pelo-covid-19/. Acesso em: 10 fev. 2021; "Casal infetado com Covid-19 deu o nó no hospital", site da RTP, televisão nacional (do estado) de Portugal, disponível em: https://www.rtp.pt/noticias/mundo/missao-da-oms-a-china-origemdo-sars-cov-2-fica-por-determinar_n1296368. Acesso em: 10 fev. 2021. Os exemplos são inúmeros, basta pesquisar a expressão "infetado com covid". 
resultado da infeção. Por exemplo, num título que vários órgãos de comunicação social usaram em 13/9/2020 “Guarda redes do Benfica infetado com COVID-19"26 deveria ser "Guarda redes do Benfica infetado com o vírus corona tem COVID19". Ou ainda títulos que se não fosse o funcionamento metonímico seriam absurdos, como "COVID-19 ajuda zonas com menos turismo" 27. Aqui COVID-19 equivale a vírus ou à situação global criada e não à doença. Não é quem está doente ou a própria doença que ajudam as zonas que antes da pandemia tinham menos turismo, mas a situação social (as pessoas procurarem para férias zonas pouco frequentadas) provocada pelo vírus.

Temos, portanto, que expressões como "vírus SARS-CoV-2”, “COVID19", “coronavírus" e mesmo "pandemia" podem funcionar como metonímias entre elas, como o esquema da Figura 10 permite visualizar.

Figura 8 - Correspondência metonímica dos termos relativos ao vírus

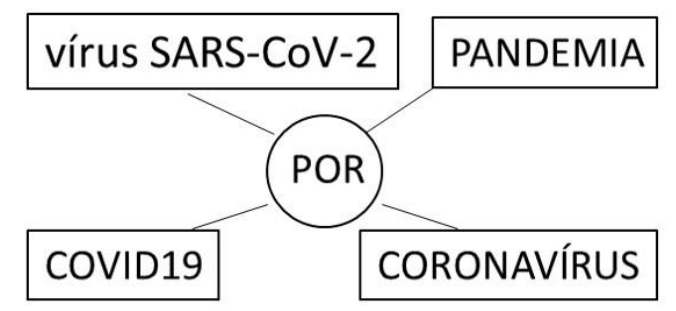

Fonte: esquema do autor

Esta equivalência metonímica permite que os domínios-alvo (víruspandemia-COVID 19-coronovírus) se fundam cognitivamente e facilitam a construção de inúmeras metáforas que podem ilustrar o conceito de metáforas em cascata que David, Lakoff and Stickles (2016) apresentam:

\footnotetext{
26 Jornal Correio da Manhã online. Disponível em: https://www.cmjornal.pt/desporto/detalhe/guarda-redes-do-benfica-infetado-com-covid-19. Acesso em: 10 fev. 2021.

${ }^{27} \mathrm{O}$ maior título em toda a primeira página do jornal impresso de distribuição gratuita $O$ Destak de 14/09/2020.
} 
The novelty of the proposed developments lies in the introduction and formal implementation of the concept of metaphoric cascades in metaphor analysis. A cascade is a hierarchically organized conceptual combination of image-schemas, frames, and metaphors that has been used ofen enough to become fixed as a single complex entity, though each of its parts continues to occur separately. (DAVID; LAKOFF; STICKLES, 2016, p. 215)

A partir da forma como a imprensa portuguesa referencia o domínio-alvo constituído por este vírus fomos recolhendo um corpus que demonstra a enorme quantidade e variedade de metáforas que servem de domínio-fonte. Não se podem, aqui, apresentar todas as ocorrências desse corpus, mas, para mostrar como realmente as metáforas covidianas se organizam em cascata e que, como refere a proposta teórica de David, Lakoff and Stickles, compõem redes hierárquicas coerentes ("A noção de cascata baseia-se na observação feita na semântica de frames de que os frames são conjuntos de papéis coerentes dinamicamente relacionados uns com os outros"28 (DAVID; LAKOFF; STICKLES, 2016, p. 215).

Assim, poder-se-á elaborar a estrutura geral das mais salientes metáforas covidianas encontradas na imprensa portuguesa. Essa estrutura, como não podia deixar de ser, mostra-se assente nas dimensões cognitivamente mais salientes atribuídas ao vírus, que constituem as metáforas mais básicas e de nível superior: VÍRUS É SER QUE SE MOVE; VÍRUS É AGENTE; VÍRUS É (MILITAR) INIMIGO. E é desta última dimensão que decorrem as metáforas de guerra, que poderiam verbalizar-se como LUTAR CONTRA O VÍRUS É GUERRA, mas mais adequadamente como PROTEÇÃO (CONTRA O VÍRUS) É GUERRA²9. A Figura 11 representa essa estrutura geral metafórica, e as Figuras 12, 13, 14 e 15 as

28 "The notion of a cascade builds on the observation made in frame semantics that frames are bundles of coherent roles dynamically related to one another".

${ }^{29}$ Expressões muito frequentes como "proteger-se é a melhor arma", "distanciamento social é a melhor defesa", "ficar em casa é a única arma que temos" mostram a abrangência aqui do conceito de luta que inclui a proteção de cada um. 
metáforas mais destacadas que encontrámos na imprensa escrita e que exemplificam e desenvolvem em cascata o referido esquema de base.

Figura 9 - Estrutura global das metáforas covidianas

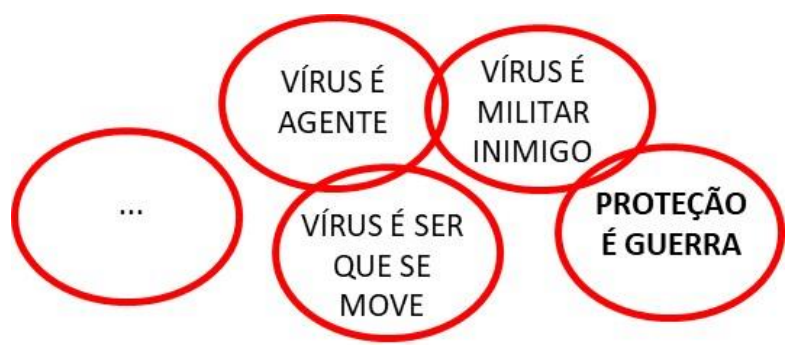

Fonte: esquema do autor

Figura 10 - Rede de metáforas do ramo VÍRUS É SER QUE SE MOVE

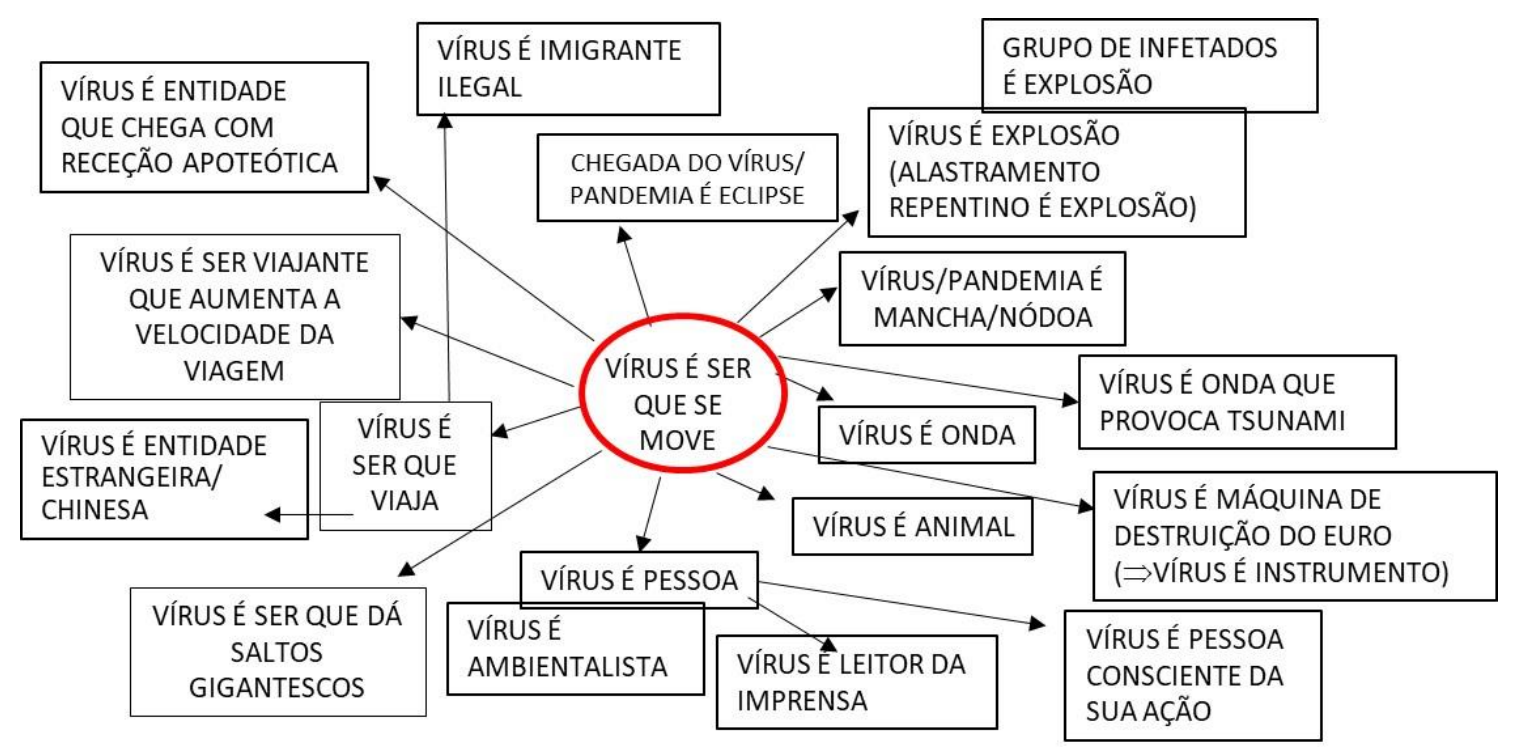

Fonte: esquema do autor 
Figura 11 - Rede de metáforas do ramo VÍRUS É AGENTE

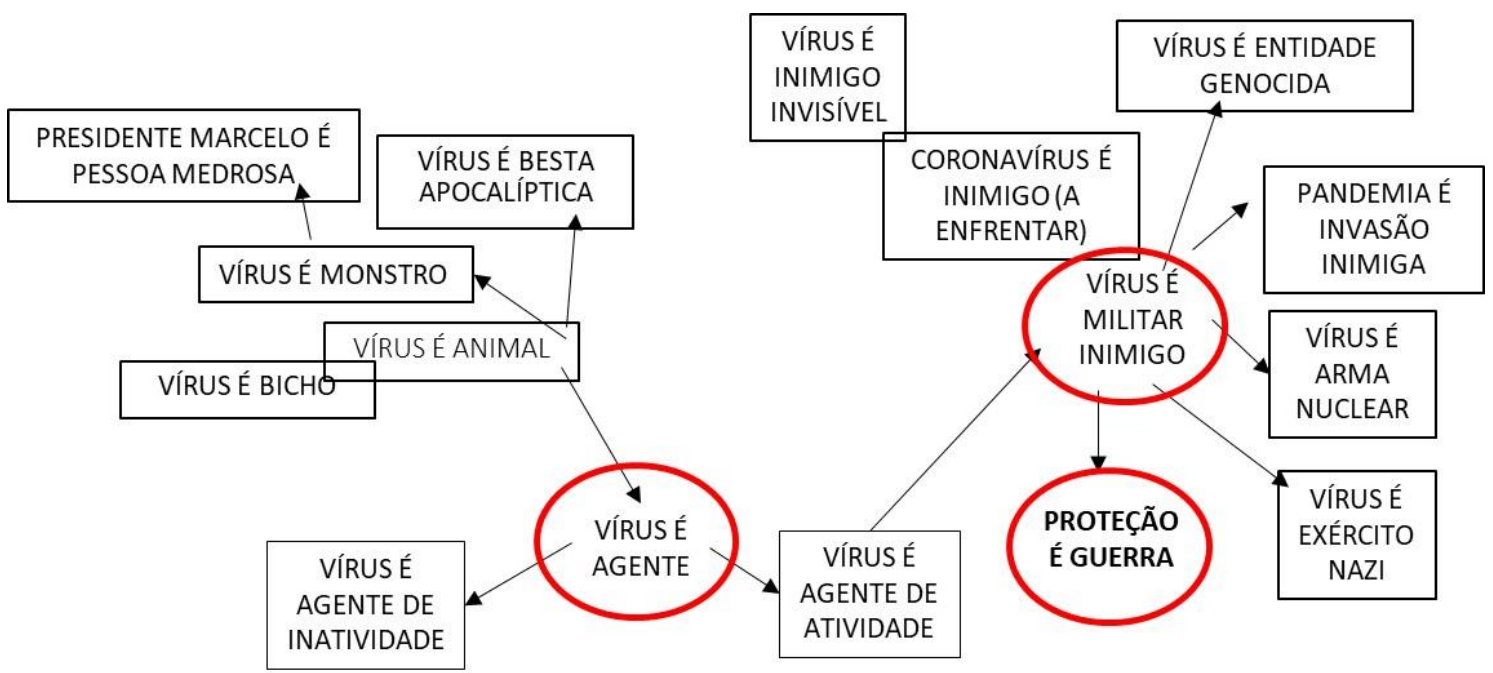

Fonte: próprio autor

Figura 12 - Rede de metáforas do ramo PROTEÇÃO É GUERRA

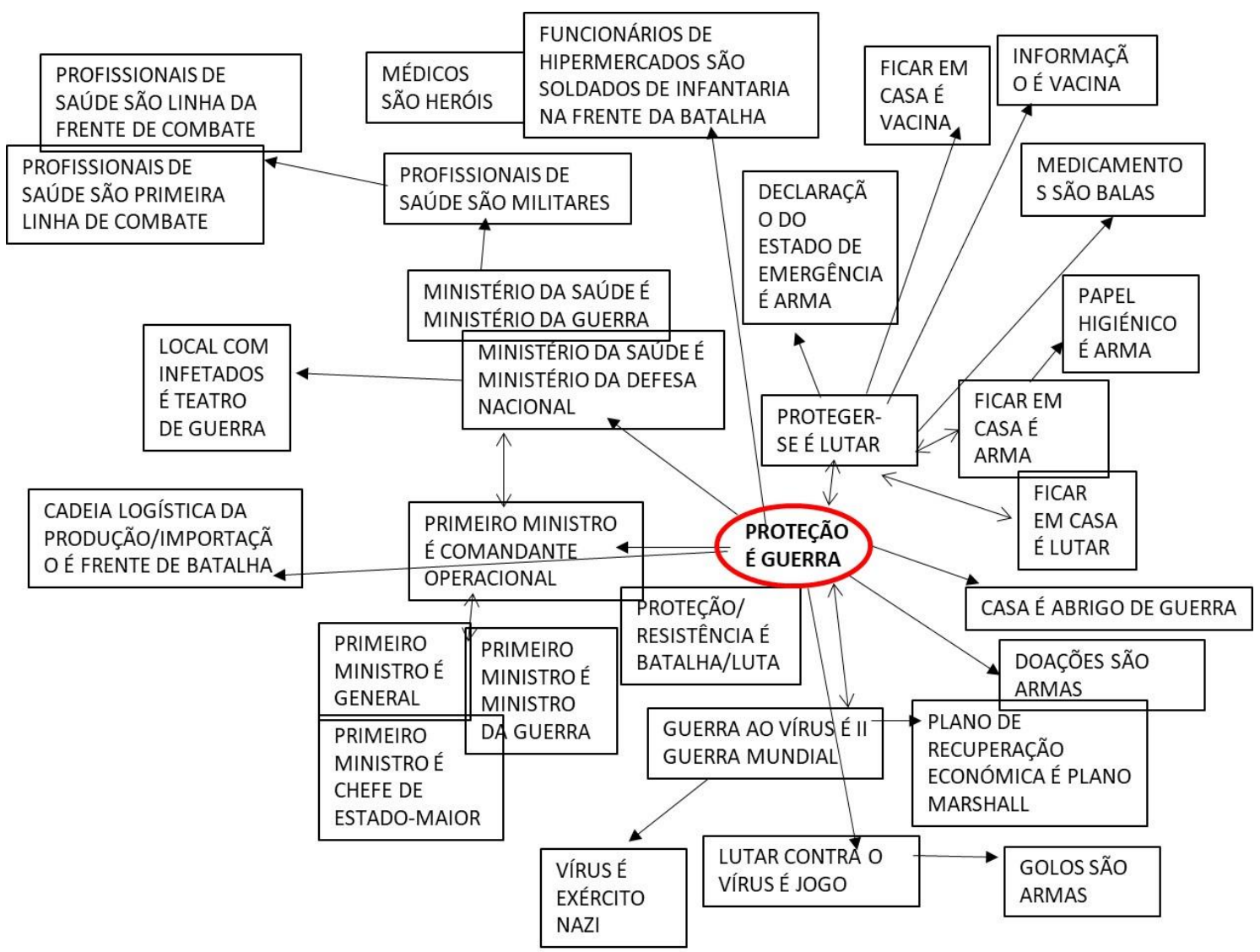

Fonte: próprio autor 
Figura 13: Rede de metáforas do ramo VÍRUS É AGENTE DE ATIVIDADE

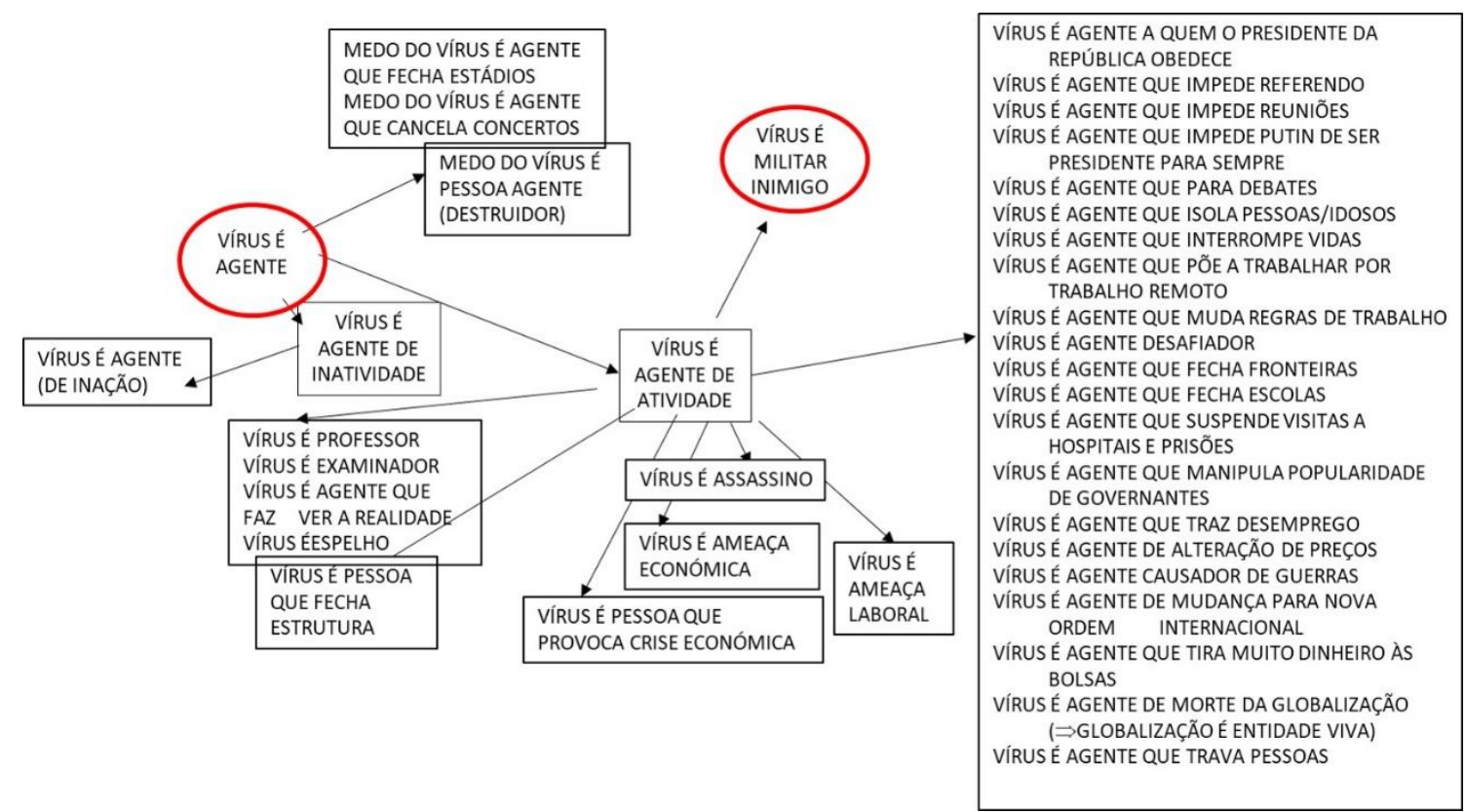

Fonte: próprio autor

\section{FOCANDO O ESSENCIAL}

Naturalmente que não foi objetivo deste texto a explanação de toda a rede metafórica usada pela imprensa portuguesa na veiculação das notícias da situação da COVID-19. Nem sequer se analisaram nem elencaram todas as metáforas relativas a PROTEÇÃO (CONTRA O VÍRUS) É GUERRA, inúmeras e muito variadas, como na Figura 14 se pode vislumbrar. O essencial, para este texto, é o de tentar refletir sobre a difícil questão da tradicional separação entre denotação-conotação, sentido literal-figurado, sentido não metafórico-sentido metafórico. A longa tradição em que estas dicotomias assentam alia-se à perceção dos falantes que, mesmo não sendo linguistas, intuem diferenças entre os dois planos de significado. Será, portanto, contraintuitivo negar que os dois planos existem, mas isso não pode significar uma visão rígida que separa esses planos como instâncias paralelas de significado. Esses planos têm de ser vistos como de distanciação dinâmica, como de relação dinâmica de significado, dinamismo esse que relembrando os conceitos de metaforicidade e de figuratividade pode fazer 
variar em grau ou intensidade a distância não figurado-figurado (ou denotaçãoconotação, não metafórico-metafórico). Na Figura 9, atrás apresentada, procuramos que se visualize a forma como se pode conciliar a existência dos dois planos tradicionais com a perspetiva cognitiva do significado lexical como estrutura dinâmica assente em modelos de prototipicidade. Até porque esta variabilidade de intensidade figurativa não afeta a eficácia comunicativa e cognitiva da metáfora, antes pelo contrário: é a diminuição da distância semântica entre o metafórico e o não metafórico que dá o extraordinário poder a estes níveis que tem a metáfora PROTEÇÃO (CONTRA O VÍRUS) É GUERRA. Por isso, ela estar a ser tão popular em culturas e nações muito diferentes, por isso ela ser obsessivamente usada, sobretudo por líderes governamentais que lhe querem dar importância como se dá a um inimigo e assim aparecerem como verdadeiros salvadores nacionais ${ }^{30}$., e ampliada pela comunicação social, aceite e reutilizada popularmente nas conversas do cotidiano.

Metaphors we live by foi a afirmação que iniciou a metáfora concetual. A pandemia da COVID-19 permite verificar que as metáforas também servem para lutar, Metaphors we live (fighting) by e que, portanto, também as metáforas da vida covidiana são, para o bem e para o mal, hoje, metáforas da vida cotidiana.

\section{REFERÊNCIAS}

BARCELONA, A. (ed.) Metaphor and Metonymy at the Crossroads: A Cognitive Perspective, Berlin: Mouton de Gruyter, 2000.

COULSON, S.; OAKLEY, T. Blending and coded meaning: Literal and figurative meaning in cognitive semantics. Journal of Pragmatics, v. 37, n. 10, p. 1510-1536, 2005.

\footnotetext{
${ }^{30}$ Os líderes nacionais (Presidentes Bolsonaro, Trump e poucos mais) que não partilharam estes frames (podemos dizer, esta estrutura cognitiva) e não quiseram perspetivar o combate à pandemia como uma guerra, mas como algo banal ("uma gripezinha", "nada de especial", "com o calor o vírus vai morrer") ou mudaram de opinião ou sofreram fortes perdas de popularidade.
} 
DAVID, O.; LAKOFF, G.; STICKLES, E. Cascades in metaphor and grammar - A case study of metaphors in the gun debate. Constructions and Frames, v. 8, n. 2, p. 214-255, 2016.

DUNN, J. Gradient semantic intuitions of metaphoric expressions. Metaphor and Symbol, Oxford, v. 26, n. 1, p. 53-67, 2011.

GIORA, R. Literal vs. figurative language: Different or equal? Journal of Pragmatics, v. 34, p. 487-506, 2002.

GOOSSENS, L., Metaphtonymy. The interaction of metaphor and metonymy in expressions for linguistic action. Cognitive Linguistics. v. 1, n. 3, p. 323-340, 1990.

LAKOFF, G. "Embodied Minds and Meanings". In: BAUMGARTNER, P. e PAYR, S. (Edit.), Speaking Minds - Interviews with Twenty Eminent Cognitive Scientists, Princeton, Princeton University Press, 1995.

LAKOFF, G. Women, Fire, and Dangerous Things: What Categories Reveal about the Mind, Chicago/London: The University of Chicago Press, 1987.

LAKOFF, G.; JOHNSON, M. Metaphors We Live By. Chicago: The University of Chicago Press, 1980.

MÜLLER, C. Are "deliberate" metaphors really deliberate: a question of human consciousness and action. Metaphor and the Social World, Amsterdam, v. 1, n. 1, p. 61-66, 2011.

MÜLLER, C. What gestures reveal about the nature of metaphor. In: CIENKI, A.; MÜLLER, C. (Edts). Metaphor and Gesture, Amsterdam, John Benjamins Publishing Company, 2008, p. 219-245.

ROSCH, E. Cognitive representations of semantic categories. Cognitive Psycology. 7, p.573-605, 1975.

ROSCH, E. On the internal structure of perceptual and semantic categories. In: MOORE, T. (Ed.). Cognitive Development and the Acquisition of Language. New York: Academic Press, p. 111-144, 1973.

SAPOLSKY, R. M. Comportamento: a biologia humana no nosso melhor e pior. Tradução por Giovane Salimena, Vanessa Bárbara. Lisboa: Temas e Debates - Círculo de Leitores, 2018.

TEIXEIRA, J. As cores dos provérbios na língua portuguesa: de Portugal ao Brasil e de Angola a Timor. Studia Iberystyczne. 18, p. 537-561, 2019b. Disponível em http://hdl.handle.net/1822/63156. Acesso em: 16 set. 2020.

TEIXEIRA, J. As cores no processamento do significado: provérbios e sinestesia. Revista Galega de Filoloxía. v. 19, p. 131-149, 2018. DOI: https://doi.org/10.17979/rgf.2018.19.0.4950. Disponível em: http://hdl.handle.net/1822/59148. Acesso em: 16 set. 2020.

TEIXEIRA, J. Categorização e concetualização: da metáfora/metonímia e sinestesia à 'sintonímia'. In: ALMEIDA, A. A. D. A categorização em Linguística Cognitiva: organizando conhecimentos. Salvador/BA: EDUFBA, 2021 (no prelo). 
TEIXEIRA, J. Organização conceptual das categorias e a lexicalização de um protótipo (fruta), Diacrítica Série Ciências da Linguagem, Braga, n. 19/1, p. 239-280, 2005. Disponível em: http://hdl.handle.net/1822/4509. Acesso em: 16 set. 2020.

TEIXEIRA, J. Significado e cores de nove provérbios portugueses sem cor. In: MARQUES, M. A.; SÁNCHEZ REI, X. M. (Eds.). Estudos atuais de linguística galegoportuguesa. Santiago de Compostela: Edicións Laiovento, p. 263-292, 2019a. Disponível em: http://hdl.handle.net/1822/61026. Acesso em: 16 set. 2020.

TEIXEIRA, J. Texto jornalístico e metáforas de vida e morte no futebol. In: SILVA, A. S.; MARTINS, J. C.; MAGALHÃES, L.; GONÇALVES, M. (Orgs.). Comunicação, Cognição e Media. Braga: Publicações da Faculdade de Filosofia, Universidade Católica Portuguesa, 2010, p. 305-322. v. 2. Disponível em: http://hdl.handle.net/1822/11258. Acesso em: 16 set. 2020.

Nota do editor:

Artigo submetido para avaliação em: 11 de novembro de 2020.

Aprovado em sistema duplo cego em: 04 de fevereiro de 2021. 